\title{
A comparison of mathematics questions in Turkish and Canadian school textbooks in terms of synthesized taxonomy
}

\author{
Ümit Kul \\ Artvin Coruh University, Faculty of Education, Artvin, Turkey, umitkul@artvin.edu.tr \\ orcid.org/0000-0002-3651-4519 \\ Eyüp Sevimli \\ Gaziosmanpasa University, Faculty of Education, Tokat, Turkey, eyup.sevimli@gop.edu.tr \\ orcid.org/0000-0002-2083-688X \\ Zeki Aksu \\ Artvin Coruh University, Faculty of Education, Artvin, Turkey, zekiaksu25@artvin.edu.tr \\ orcid.org/0000-0001-6839-6847
}

\begin{abstract}
The present study offers a comparative analysis of mathematics questions placed in Turkish and Canadian school textbooks in terms of cognitive process and knowledge dimension as well as the question types. In order to get the required data, eight textbooks were analyzed respectively. Document analysis was conducted to collect the data from these textbooks. In order to compare the differences and similarities between the questions found in these textbooks as well as their levels of cognitive learning, these questions were analyzed and classified according to the types of cognitive processes and knowledge dimensions they address. Mathematics questions existing in Turkish and Canadian textbooks showed a similar tendency in terms of cognitive learning domain. However, compared to the Turkish textbooks, it was found that the questions provided in the Canadian textbooks contained more constructed response questions that required higher-order cognitive abilities. It is recommended that the number of higher order thinking questions should be increased in accordance with international examinations.
\end{abstract}

Keywords Mathematics textbook, Comparative education, Synthesized taxonomy

\section{Türkiye ve Kanada matematik ders kitaplarındaki soruların sentezlenmiş taksonomiye göre incelenmesi}

ÖZ Bu çalıșmanın amacı, Türkiye ve Kanada'da kullanımda olan ortaokul matematik ders kitaplarındaki soruları bilişsel öğrenme düzeylerine ve soru türlerine göre inceleyip karşılaştırmaktır. Bu bağlamda Türkiye'de kullanımda olan ortaokul matematik ders kitapları ile Kanada' da kullanımda olan "Math Makes Sense" adlı ders kitapları içerik analizine tabi tutularak karşılaştırılmıştır. Araştırmanın amacına uygun olarak veriler toplanıp doküman analizi yapılmıştır. Her iki ülke ders kitaplarında yer alan matematik soruları, Sentezlenmiş Bloom Taksonomisi üzerinden bilișsel süreç ve bilgi boyutlarına göre kodlanmış ve soruların bilişsel öğrenme düzeylerine göre benzerlik ve farklılıkları karşılaştırmalı olarak incelenmiştir. Türkiye ve Kanada ders kitaplarında yer alan soruların bilişsel süreç ve bilgi boyutu açısından benzer özellikler gösterdiği tespit edilmiştir. Ancak Kanada ders kitabında bilişsel beceri gerektiren açık uçlu soru türlerine daha çok yer verildiği belirlenmiştir. Ders kitaplarının içeriği oluşturulurken uluslararası sınavlarla uyumlu üst bilişsel beceri gerektiren sorulara daha fazla yer verilmesi önerilmektedir.

Anahtar Kelimeler Matematik ders kitabı, Karşılaştırmalı eğitim, Sentezlenmiş taksonomi

Cite This Article:

Kul, Ü., Sevimli, E., \& Aksu, Z. (2018). A comparison of mathematics questions in Turkish and Canadian school textbooks in terms of synthesized taxonomy. Turkish Journal of Education, 7(3), 136-155. DOI:10.19128/turje.395162 


\section{INTRODUCTION}

Considering its role in the development of the individual and society, it is possible to claim that mathematics is one of the fundamental subjects that should be taught at all levels of educational systems. Due to the multitude of large-scale examinations and their impact on the lives of individuals, the way in which mathematical knowledge is measured becoming more and more important each day. Recent studies have shown substantial differences between the mathematical achievements of student across the worldwide. These difference have been expressed by international examinations like Trends in International Mathematics and Science Study [thereafter TIMSS] and the Programme for International Student Assessment [thereafter PISA]. According to the TIMSS 2015 report, in terms of $8^{\text {th }}$ grade mathematics success, Canada is ranked as $8^{\text {th }}$ with the highest mathematics success among Englishspeaking countries, and Turkish students ranked $24^{\text {th }}$ with a score of 458 . In the PISA mathematics result, Canadian students are ranked as $7^{\text {th }}$ with a score of 516, and Turkish students are ranked as $52^{\text {nd }}$ with a score of 420 . When the results of TIMSS and PISA are compared, it is revealed that the mathematics success of Turkey was below the mean of the participating countries (ÖDSGM, 2016).

One of the significant instruments employed in clarifying the possible reasons for the differences in achievement determined through a large-scale examination is the comparison of textbooks (Alajmi, 2012; Son, 2012). The quality of the textbooks used in a class contributes to the effectiveness of the teaching and learning process, and one can compare countries' mathematical achievement ranks and textbook quality according to international-scale examinations (Delil \& Tetik, 2015; Fan, Zhu \& Miao, 2013; Kulm \& Capraro, 2008; Sevimli \& Kul, 2015). Additionally, there are studies showing that there is a strong correlation between the mathematical achievements of students and the quality of the textbooks used (Fan, Zhu \& Miao, 2013; Kulm \& Capraro, 2008). The majority of textbooks and lesson notes generally focus on shaping the content of mathematical knowledge to be taught and learned and have the quality of a guidebook (Haggarty \& Pepin, 2002; Hirsch, Lappan, Reys \& Reys, 2005; Thomson \& Fleming, 2004). In their study, Alajmi and Reys (2007) stated that if a topic is not included in the textbook, most probably this topic will not be mentioned in class. Hence, while preparing textbooks, relevant parties' attention should be on the selection of content appropriate to the characteristics of the behavior to be measured.

One prominent argument in this debate may be on the quality of textbooks used in the classrooms and how this quality might and should be used as a criterion to compare the ability of educational systems which compete internationally in today's world. The quality of the textbooks might be assessed by looking at the questions provided in the textbook and this study offers this kind of analysis. The present study offers a comparative analysis of mathematics questions placed in Turkish and Canadian school textbooks in terms of cognitive process and knowledge dimension as well as the question types. Questions addressing higher cognitive thinking levels increase the conceptual learning level of students and may aid in the consolidation process (Duman et al., 2001). Considering with other factors influencing the low mathematics achievement of countries, the role of compatibility or incompatibility between teaching content and examination content in success or failure is undeniable. Textbooks with time and duration incompatibility between classes make the end result, examination important in terms of cognitive processes and knowledge dimensions of mathematics lesson content at the same level in different countries and schools. Investigating the cognitive characteristics of activities used in the mathematics education of countries having different success rankings may help to identify the strengths and weaknesses of textbooks used in countries. The purpose of this research is to reveal the differences in mathematics achievements of Turkish and Canadian students, hence contributing to the international comparative studies in this area. In this study, we have not only discussed the comparative educational research focusing the educational systems, teaching content and teacher practices in different countries, but also have provided comparisons of teaching practices among Turkey and Canada.

The examination of textbooks might illustrate how teaching and learning occurs in a large population (Li, Chen \& An, 2009). As a result, the examination of these textbooks will identify the kinds of learning 
opportunities that the Canada and Turkey provide their students, and it will elicit the differences and similarities in their teaching process. These findings might contribute to the development of teaching materials. In the current research, selected Canadian and Turkish mathematics textbooks were compared by concentrating on their cognitive level of the mathematics questions at the end of units. It is important for researchers to determine the differences in student achievement and learning opportunities between different countries. In this study, evaluation questions at the end of units in mathematics textbooks used in both Turkey and Canada are assessed in terms of components of Synthesized Bloom Taxonomy (SBT) such as 'cognitive processes' and 'knowledge dimension'. With this aim, the following research questions guided our study: 1) What is the level of mathematics questions in middle school mathematics textbooks in Turkey and Canada according to the Synthesized Bloom Taxonomy? 2) Are there differences between the types of mathematics questions in middle school mathematics textbooks in Turkey and Canada? The results obtained from this study are important because of that a comparative assessment was made on the cognitive field taxonomy, taking into account the content of the students' learning process and countries' mathematical achievement ranked in the large-scale examinations (Haggarty \& Pepin, 2002; Törnroos, 2005).

\section{The Context of Study}

The Turkish education system consists of kindergarten, primary, secondary and higher education. Primary education level defines and is limited to the teaching of pupils aged from 6 to 14 and is compulsory for all citizens, whereas the higher education level is optional. Both the state and the private primary schools are governed and monitored by an official branch representing the Turkish Republic, and this branch is called as the Ministry of National Education (thereafter MONE). The regulations issued by MONE promote and define a standard mathematics curriculum, and all teachers serving the relevant grade level have to follow this curriculum. As a result of reform movements, which took place in mathematics education globally, there was a need to review national educational policies, learning outcomes and teaching paradigms in Turkey and prepare a new curriculum that would meet this need. In this direction, there has been a transition from a behavior-focused system and rote based learning system in mathematics curriculum to an in-class learning-focused system emphasizing upper level skills and aiming to improve conceptual understanding (Babadağ \& Olkun, 2006; Baki, 2008; Bulut, 2007; Sriraman, 2010). Thus, changes that took place in the Turkish mathematics curriculum of 2005 were organized modelling the curriculum programs implemented in countries such as England, the United States of America, Canada and Singapore (Olkun, 2006). The basic aims of this curriculum may be listed as to ensure effective student participation in the learning program, present the opportunity for students to construct their own mathematical knowledge, improve the mathematical thinking skills of students as well as helping them to gain problem-solving skills (Bulut, 2007; MONE, 2017). In Canada, each one of the provinces and territories has one or two departments responsible for education, headed by a minister. These departments concentrate only on the guiding the education of the country. Unlike the education system present in Turkey, authority and responsibility were given to the local authorities.

Canadian children under the age of six and 16 must attend school and most of them go to public schools. Similar to Turkey, elementary and high schools usually start in early September and end in late June. The curricula in Canada is prepared by one of the official organizations of education departments linked to this ministry. In order to enter to university in some provinces of Canada, such as British Columbia, students must have a high school diploma and have been successful in the University Entrance Exams in addition to school examinations. The Canadian mathematics curriculum follows a conceptual approach which concentrating on the processes of critical thinking, problem solving and real-world applications. The similarities in the educational process, semesters and program paradigms between Turkey and Canada provide the opportunity to compare the two countries with a descriptive approach.

As such, it is necessary to discuss the developmental properties of the mathematics textbooks from Turkey and Canada. In both countries, private publishers may prepare textbooks in accordance with the national curricula with permission of the ministry or department of education. In Turkey, an enormous investment was made in providing textbooks for all subjects and distributing them to schools free of 
change. In Canada, there is no requirement for teachers and students to use and follow previously determined textbooks (Mullis, Martin, Foy \& Arora, 2012). Compared with Canada, variation and updating studies of the curriculum and textbooks are performed more often in Turkey. The textbooks in Turkey must be designed accordingly with the previously announced curricula, and the weekly distribution of topics is pre-determined while the teachers are expected to teach these topics. However, teachers in Canada have more flexibility in terms of the elements to be followed during teaching using textbooks. Textbooks have a significant effect on learning and teaching as content must reflect the content of the curricula (Stein, Remillard \& Smith, 2007; Pepin \& Haggarty, 2001).

\section{Conceptual Framework}

In the educational policies in countries, measurement and assessment are dealt with as part of instruction. With the aim of measurement and assessment, a variety of taxonomies are used to reflect the content and quality of questions. The Bloom's taxonomy is one of the most widely accepted systematic classifications used for classification not only in the field of cognitive learning, but also in many other areas including mathematics. The taxonomy developed by Bloom (1956) is about the cognitive learning field and suggests there are six hierarchical levels of knowledge, comprehension, application, analysis, synthesis and evaluation (Bloom, 1956). In their work, Smith, Wood, Coupland and Stephen (1996) noticed some limitations of Bloom's taxonomy and defined the MATH taxonomy, a variation of Bloom's taxonomy specific designed to the field of mathematical learning, with the aim of assessing students' understanding of mathematics. When the levels of both taxonomies are investigated in detail, it is possible to see the "application" stage in Bloom's taxonomy is divided into 3 different stages respectively and they are discussed more thoroughly compared to the MATH taxonomy. The "synthesis" level of Bloom's taxonomy is determined to be equivalent to the "inferences, estimations and comparisons" stage in the MATH taxonomy. The most important characteristic separating two taxonomies is that the MATH taxonomy developed by Smith and his colleagues pays more attention to the content relatedness among mathematical concepts. Porter (2002) assessed the stages of "knowledge" and "comprehension" under the name "memorizing" to assess teaching content (curriculum and textbooks).

Anderson and Krathwohl (2001) reorganized Bloom's classification and dealt with two different dimensions of the "knowledge dimension" and the "cognitive processes dimension". These constitute the knowledge dimension showing the content of learning outputs/questions and the cognitive processes dimension showing how these targets are achieved. Thus, this two-dimensional revised taxonomy allows the opportunity to assess cognition, not just in terms of knowledge, but simultaneously in terms of processes (Krathwohl, 2002). The knowledge dimension comprises the factual, conceptual, procedural and metacognitive levels with detailed information about their definitions and contents available in the study (ibid). The cognitive processes dimension increases in complexity and scope moving from left to right, while the knowledge dimension increases from top to bottom. To increase the complexity, scope and abstraction, it is necessary for educators to perform detailed investigations about the levels of questions. Instead of just correlating knowledge to one content, an attempt is made to deal with knowledge accumulation that aids in completing cognitive processes at the same time. However, it may not always be possible to determine definite boundaries between the dimensions and the levels within these dimensions.

The questions on TIMSS are classified in terms of skill levels in three cognitive areas of knowing, applying and reasoning. This framework is only used to assess cognitive learning domains of problems However, the study by Rivzi (2007) compared and synthesized some taxonomies to develop a new taxonomy. This new taxonomy provides an opportunity to assess cognition in terms of knowledge cognitive processes dimension. According to Rivzi, there are similarities between some levels in Bloom's taxonomy and this situation makes classification difficult. This particular study stated the cognitive process stages in available taxonomies (Biggs, 1995; Bloom, 1956; Smith et al., 1996; Porter, 2002) overlapped and identified different levels to develop a new taxonomy called the Synthesized Bloom Taxonomy (SBT). According to the SBT, the first stage of the cognitive learning field specific 
to mathematics is "assimilation". At the first domain, the student knows the definitions of basic mathematical concepts, facts and formulae, can make sense of familiar situation and activities and use these to solve routine problems. After the assimilation domain, the student is expected to reach the "transformation". A student at the transformation level can understand the solutions to non-routine mathematical problems or adapt themselves to new situations due to the accumulation of knowledge gained during the previous stage. Questions in the transformation stage should test the ability to transform knowledge from one form to another, from verbal to numerical. The second domain concentrates on the skills of learners to apply knowledge and conceptual understanding to solve questions. Finally, the "creation and validation" stage is reached where the individual should be able to estimate mathematical relationships, prove, confirm, make generalizations, assess and reconstruct knowledge as a new unit. The last stage, reasoning, goes beyond the solution of routine questions to comprehend unfamiliar circumstances, complex contexts, and multi-step problems. The creation and validation stage in SBT is equivalent to the combination of the evaluation and synthesis belongs to stages of the revised Bloom taxonomy. In the SBT the questions in the curriculum and textbooks are analyzed in two dimensions of the cognitive processes and the knowledge dimension (Rivzi, 2007). The dimensions and sub-dimensions of the SBT used in this study are shared in detail in the data analysis section (see Table 2 and 3 ).

\section{Relevant Research}

Textbooks are seen an essential material for both students and teachers. According to Pepin and Haggarty (2001), the subject of mathematics in the classroom is intensely affected by the existing textbooks, since most teachers prefer to use them as their main teaching materials. This argument is supported by a study conducted by Rezat in 2009. In this study, Rezat (2009) emphasized the importance of using textbooks in the teaching and learning process. According to the tetrahedron model developed specifically for the field of mathematics education by Rezat (2009), the interaction between teachers, learners, textbooks and mathematical knowledge should be used to explain the quality of the teaching and learning processes. In recent years, various studies have explored the textbooks because of their important position in the process of teaching and learning. When comparative studies in the relevant literature are investigated thoroughly, it has been noted that the context of design, language, content, teaching activities and questions in textbooks from two or more countries are assessed in terms of similarities and differences (Erbaş, Alacacı \& Bulut, 2012; Haggarty \& Pepin, 2002; Kar, Güler, Şen \& Özdemir, 2017). For example, Haggarty and Peppin (2002) completed a study comparing the most popular mathematics textbooks in England, Germany and France. The results of their study found that English textbooks had a tendency to show mathematics as a discipline where learning was mandatory, with accuracy simply accepted and comprised of rules and processes. German textbooks had lower levels of difficulty in mathematics questions compared to textbooks from other countries, while the questions in French textbooks included mathematical activities mainly based on daily life. Another study comparing the mathematics questions in middle school 8th grade level of mathematics textbooks on a country basis was conducted by Özer and Sezer (2014), and they stated that compared to textbooks from Singapore, there was more overlap between American and Turkish mathematics textbook contents. Their study observed that in American and Singaporean textbooks questions addressing to the higher levels of comprehension were more frequent, while the questions in Turkish books generally addressed the lower levels of comprehension as they focused on answering the question rather than the solution method. Kar et al. (2017) investigated the methods used for multiplication of fractions in Turkish and American textbooks. The result of this study showed that the mathematics questions provided in American textbooks had a style requiring more high-level cognitive skills. The basic difference revealed in this study is that the primary aim of American textbooks is to develop conceptual understanding primarily followed by procedural skills, while in Turkish textbooks the aim is to develop both simultaneously.

When studies in Turkey are investigated, they appear to focus mainly on student and teacher opinions of the choice or lack of choice in the use of learning and teaching in textbooks. Within this scope, the focus has been on qualities like the technical properties of the textbooks, activities in the textbooks and 
problem state or application principles (Bingölbali, Gören \& Arslan, 2016; Erbaş, Alacacı \& Bulut, 2012; Kurtulmuş, 2010; Sevimli, 2016; Taşdemir, 2011). There are a limited number of studies available that assess questions in textbooks in terms of knowledge and cognitive processes dimensions of the cognitive learning field (Biber \& Tuna, 2017; Karadeniz et al., 2015). Ubuz and Sarpkaya (2014) observed that while the algebraic tasks in 6th grade textbooks required high levels of cognitive thinking, the levels of applications in class were low. Another study relevant to the issue at hand is conducted by Biber and Tuna (2017), and in this study they stated that the number of questions belonging to the analysis, synthesis and evaluation levels among the exercise questions found in Turkish textbooks were very low. There is no study investigating the cognitive level of the mathematics questions in Turkish textbooks along with those from another country in terms of SBT dimensions. The present study compares Canada and Turkey on how they sustained mathematical success in international examinations. This study provides insights into the similarities and differences in the cognitive learning levels of questions in Canadian textbooks, with proven student success, and Turkish textbooks. In this way, it is important for researchers to determine the differences in student achievement and learning opportunities between different countries.

\section{METHODOLOGY}

In accordance with the aim of the research, data were collected with document analysis. Document analysis, known as the investigation process based on cases with the research focus on written material, records or documents, is generally used in educational studies when textbooks and curricula are the data source (Y1ldırım \& Şimşek, 2008). The documents in this research are available middle school mathematics textbooks from Turkey and Canada and the exercise questions within these documents were analyzed accompanied by their relevant conceptual frameworks. While completing comparative document analysis, it is important to explain the context of the written sources from which data are obtained (Bowen, 2009).

\section{Selection of Textbooks}

According to the examination results of the international TIMSS (2015), as the mathematical achievement of $8^{\text {th }}$ class students in Turkey was below the mean success points and Canada was among countries with success above the mean points, the textbooks from these two countries were compared. Data were gathered from the mathematics questions at the end of the units in four Turkish and four Canadian textbooks. In Turkey, there are two types of textbooks available to be used by all teachers and students in schools with ministry approval, prepared by commissions and government-authorized textbooks. All textbooks are checked by Ministry of National Education (MONE) since the centralized nature of Turkish educational system that is based on a curriculum.

The middle school mathematics textbooks are available for all students, educators and parents and listed on the MONE official website for the 2016-2017 academic year included in the study (Table 1). These books were accepted as textbooks for a five-year duration from the year of publication by decision of the Board of Education. These books are recommended for use in many Turkish state schools; so they reach many students. The fact that textbooks are published in similar years in terms of updating are also factors affecting book selection. Four textbooks (Aydın, 2016; Aydın \& Gündoğdu, 2016; Keskin, 2016; Yaman, Akkaya \& Yeşilyurt, 2016) were examined in the present study. These textbooks do not contain any additional material.

Math Makes Sense for 5, 6, 7 and 8 grades textbooks series (Appel et al., 2008; Appel et al., 2009; Baron, et al., 2008; Garneau et al., 2007) were included in the content analysis (Table 1). One of the reasons for this book selection is that researchers can easily access and obtain these textbooks. These 
textbooks are compatible with Canadian mathematics curriculum and used in a variety of grade levels across the provinces in Canada. Authors of these textbooks assert to develop creative thinking, problem solving and understanding of mathematical ideas. The exercise questions in the evaluation sections at the end of the units in these books were used as the data tool. This study including middle school level textbooks was deemed necessary as there is no study analyzing the contents of mathematics textbooks used at this level in both countries and as the education stage is a target group for international examinations like TIMSS.

Table 1.

Content analysis of middle school textbooks

\begin{tabular}{llclc}
\hline Grade & Turkey & Number of Ques. & Canada & Number of Ques. \\
\hline 5 & Koza Publication (2016) & 106 & Math Makes Sense 5 (2008) & 101 \\
6 & Koza Publication (2016) & 154 & Math Makes Sense 6 (2009) & 74 \\
7 & Koza Publication (2016) & 105 & Math Makes Sense 7 (2007) & 129 \\
8 & Koza Publication (2016) & 174 & Math Makes Sense 8 (2008) & 184 \\
\hline
\end{tabular}

\section{Analysis of Data}

To assess the mathematics textbooks from both countries in terms of SBT in this study, the exercise questions at the end of each unit and content where students may display their performance were used. Descriptive statistical methods were used in the analysis of data. Investigation of questions in middle school mathematics textbooks was completed in 3 stages. These stages are shown in Figure 1 and explained in order.

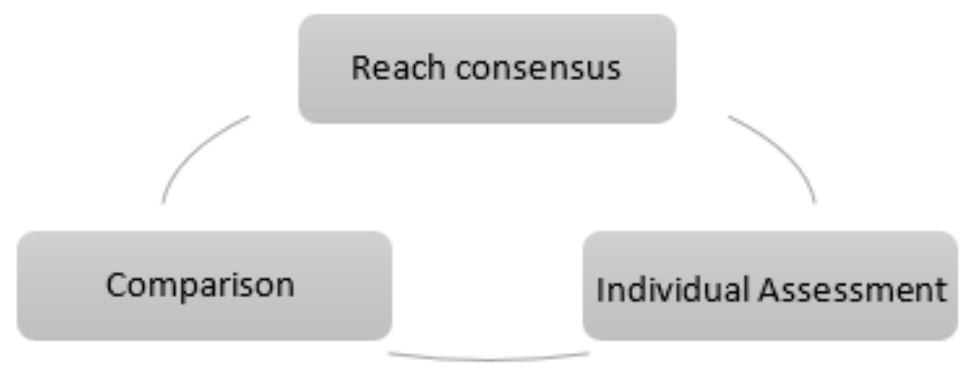

Figure 1. Stages of investigation of questions according to synthesized Bloom taxonomy

In the first stage, evaluation questions from a random unit in the textbooks from both countries were selected. Questions related to the topic were inserted on a taxonomy table by three researchers. For this, the mathematics textbooks from both countries were investigated.

Later the basic principles to be used to insert the questions from the textbooks on the taxonomy table were determined by the researchers. After keywords regarding level of questioning such as level 1 (recalling, defining, showing, classifying, recognizing), level 2 (applying, drawing, interpret, solving, analyse, generating) and level 3 (predicting, estimate, decide, criticize, justify, evaluating) were obtained in this process, the row relating to the knowledge dimension and the column relating to the cognitive processes dimension for evaluation questions at the end of units in textbooks from Turkey and Canada were identified and the location of the mathematics questions on the SBT was determined (Krathwohl, 2002).

In the second stage, the mathematics questions were independently coded by each researcher. In the third stage, the reliability between the coders was determined. In this stage the researchers met again and identified inconsistencies in the locations on the taxonomy table. These three stages continued cyclically. Later the inconsistent questions coded by researchers were discussed and a consensus was reached. During this process, if necessary, opinions were sought from an expert in measurement and 
assessment. It should be stated that each mathematics question in textbooks may be evaluated more than one cells but in this study we assume each question, evaluated just one cell.

Table 2.

Synthesized Bloom taxonomy

\begin{tabular}{|c|c|c|c|}
\hline \multirow{2}{*}{ Knowledge dimension } & \multicolumn{3}{|c|}{ Cognitive Process } \\
\hline & 1. Assimilation & 2. Transformation & 3.Creation and Validation \\
\hline \multicolumn{4}{|l|}{ A. Factual } \\
\hline \multicolumn{4}{|l|}{ B. Conceptual } \\
\hline \multicolumn{4}{|l|}{ C. Procedural } \\
\hline D. Meta-cognitive & & & \\
\hline
\end{tabular}

The horizontal axis of the SBT dimensions presented in Table 2 shows the cognitive processes dimension, while the vertical axis contains the knowledge dimension (Rivzi, 2007). Numbers on the horizontal axis are used to code levels on the cognitive processes dimension, while letters on the vertical axis code levels of the knowledge dimension. Thus, for example a while a question in B1 category requires assimilation of basic mathematical concepts, a question in the A2 category includes the skills of investigating a case in a new situation and selection of the appropriate method. Some question samples related to coding of questions in middle school mathematics textbooks used in both countries are given in Table 3. For example, the main activities in A1 category involved knowing and recalling about definitions of a triangle and a quadrilateral and its properties. The question in the A2 category includes constructing meaning from the pie chart and selection of the appropriate graph type. The question in the seventh grade of Canadian textbook may expect from students to draw a net for triangular prism and cylinder in order to identify their faces, edges and vertices. Conceptual knowledge that students need to know and use them in solving this question, therefore it is in the category of A2. Next example, using algebra tiles allow students to better understand ways of algebraic thinking and the concepts of algebra. The same cognitive level of question (B1), it is expected that students should be able to relate a percent expression to a fraction and a decimal concept and convert such concepts between each other. The first level of mathematical thinking involves solving routine questions using rule based algorithms. Another mathematics questions in the both textbooks have been categorized as B2 since it is a conceptual knowledge for students to find a rooted number, close value, or to find the range of numbers given from within the root. The student at this stage can apply his/her previous knowledge to new situations. The question in the category of B3, it is expected from student that after having conceptual knowledge about construction of triangle, it will make a judgment about whether a triangle is constructed based on a given data.

Table 3.

Coding examples of questions in Turkish and Canadian textbooks

\begin{tabular}{lll}
\hline Code & Turkey & Canada \\
\hline
\end{tabular}

Please fill in the blanks below.

A1 A quadrilateral has ......... interior angles. Describe the value of each digit in 3.675.

A triangle has three ........ and...........

The percentages of the milk

A2 following is appropriate to products collected from the dairy farms are shown in the pie chart on the right. Which of the show the data on the pie chart?

A. Histogram B. Binary line graph

C. Line chart D. Column chart

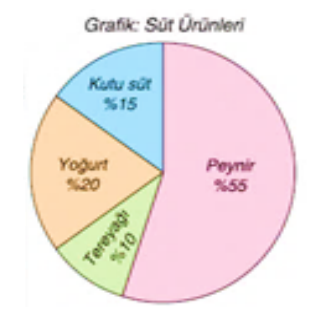

$\sqrt{75}$ and $\sqrt{136}$ estimate the approximate values of the numbers up to the nearest tenth.

Draw a net for each object.

Identify and name each face.

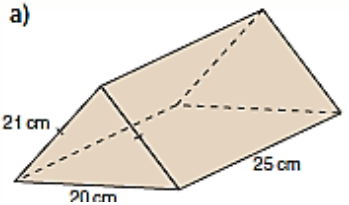

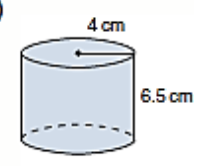

Use guess and test to estimate each square root to two decimal places. Record each trial.
a) $\sqrt{17}$
b) $\sqrt{108}$
c) $\sqrt{33}$
d) $\sqrt{79}$ 
A triangle cannot be constructed with either of the following data.
B3

$\begin{array}{rrr}\text { A. }|B C|=7 \mathrm{~cm} & \text { B. } \mid \mathrm{DFI}=6 \mathrm{~cm} & \text { C. } m(\widehat{A})=56^{\circ} \\ m(\widehat{B})=64^{\circ} & |E F|=9 \mathrm{~cm} & m(\widehat{B})=38^{\circ} \\ m(\widehat{C})=78^{\circ} & m(\widehat{F})=90^{\circ} & m(\widehat{C})=86^{\circ}\end{array}$

D. $|L M|=14 \mathrm{~cm}$ $|\mathrm{KL}|=10 \mathrm{~cm}$ $|\mathrm{KM}|=9 \mathrm{~cm}$

\section{Cloe \\ concluded that the number of 15-years old students with cell phones is about 5 times the number of 11 years old students with cell phones. Is} Cleo's conclusion correct? If yes, justify her conclusion. If not, explain how the graph may have led to the incorrect conclusion.

The below table show that the sales prices of same kind of products in different quantities belongs to the four companies and the discount applied to these prices are given. According to the table, which product is better to buy? Evaluate your decision with friends.

C3

\begin{tabular}{cccc} 
Company & $\begin{array}{c}\text { Quantity } \\
(\boldsymbol{k g})\end{array}$ & $\begin{array}{c}\text { Sales } \\
(\boldsymbol{T L})\end{array}$ & $\begin{array}{c}\text { Discount } \\
(\%)\end{array}$ \\
\hline $\mathrm{X}$ & 5 & 7 & 10 \\
$\mathrm{Y}$ & 8 & 11 & 15 \\
$\mathrm{Z}$ & 12 & 14 & 20 \\
$\mathrm{~T}$ & 15 & 24 & 25 \\
\hline
\end{tabular}

Carlton evaluated this expression: His work is below shown.

$2 \frac{4}{5} \div\left(\frac{2}{3}+\frac{1}{12}\right)=$ ? Where did Carlton go wrong? What is the correct answer?

$$
\begin{aligned}
& 2 \frac{4}{5} \div\left(\frac{2}{3}+\frac{1}{12}\right)=2 \frac{4}{5} \div\left(\frac{8}{12}+\frac{1}{12}\right) \\
& =\frac{14}{5} \div\left(\frac{9}{12}\right)=\frac{14}{5} \times \frac{9}{12} \quad{ }^{7} \quad \frac{14}{5} \times \frac{9}{12}^{3} \\
& =\frac{7}{5} \times \frac{3}{2}=\frac{21}{10}=2 \frac{1}{10}
\end{aligned}
$$

$7,12,17,22 \ldots .$. the number pattern is given. According to this;

D2
a) Model and discuss this pattern.
b) The "number of representatives" of the pattern rule express yourself using.
c) Find out the 48th step of this pattern.

An area rug is rectangle. Its dimensions are $3.4 \mathrm{~m}$ by $2.7 \mathrm{~m}$.

Discuss and show different strategies you can use to find the area of the rug. Which strategy is best? Justify your answer.

The sample question taken from the Canadian textbook and assessed as C3 category is expected to develop the students' skills of mathematical processing (procedures) and identifying errors in mathematical procedures. As a result, the aim is that the student can reach the correct generalization. According to information given in a $\mathrm{C} 3$ question from the Turkish textbook, the student is expected to choose the most advantageous from a choice of the same product offered by four companies. As a result, the student is required to assess and calculate the discounts applied to prices.

According to D2 question in Canadian 5th grade textbook, in the given case, the student has the ability to make an estimation about area of the rug and to discuss their ideas with peers. The student also in this level of question has the ability to make comparison, evaluation and judgment based on a given situation. According to information in the D2 question, students are expected to form a correlation using algorithms supporting algebraic thinking structures to determine the relevant pattern. The questions in the textbooks were classified according to cognitive learning area with each question coded according to the SBT. More coding examples are presented in the study by Rivzi (2007).

Based on the consideration that different question types may be required to present content with appropriate levels of cognitive competence, this study also analyzed the textbook content according to the composition of question types. When classifying the content according to question type, characteristics such as constructed response (open-ended), fill-in-the-blanks, multiple choice, true/false, matching and table filling were noted. 


\section{Validity and Reliability of Data}

Expert opinion was sought under the scope of the validity of the research. Three experts in the field of mathematics education determined that the levels and learning areas in the textbooks from the compared countries were similar and included all middle school mathematics textbooks and stated that there was no problem in terms of the opinions and validity of scope.

The coefficient for reliability between evaluators was used within the scope of validity of the research. In calculation of the consistency percentage between three coders, the reliability coefficient formula of Miles and Huberman (1994) of reliability = consensus / (consensus + dissidence). According to this formula, the reliability coefficient between the coders in this research was calculated as 0.84 (452/ $(452+85))$. This result means the study is accepted as reliable (Miles \& Huberman, 1994).

\section{FINDINGS}

In the present study, 1027 mathematics questions at the end of units where students may display their performance in $5^{\text {th }}, 6^{\text {th }}, 7^{\text {th }}$ and $8^{\text {th }}$ class mathematics textbooks used in Turkey and Canada are investigated according to the SBT and question types.

The questions in the textbooks are investigated in detail in terms of the knowledge dimension and the cognitive processes dimension and the obtained data are presented in Table 4 . The evaluation questions at the ends of units in Turkish textbooks are determined to be numerically higher compared to Canadian textbooks (Turkey: $n=539$, Canada: $n=488$ ). Additionally, the textbooks in both countries are similar with no content observed that could be assessed within the A3, C1, D1 and D3 categories.

Table 4.

Distribution of question in Turkish and Canadian textbooks according to SBT

\begin{tabular}{|c|c|c|c|c|c|c|c|c|c|c|c|c|c|c|}
\hline & & A1 & A2 & A3 & B1 & B2 & B3 & C1 & $\mathrm{C} 2$ & C3 & D1 & D2 & D3 & Total \\
\hline \multirow{2}{*}{ TR } & f & 103 & 40 & - & 28 & 67 & 11 & - & 282 & 7 & - & 1 & - & 539 \\
\hline & $\%$ & 19,2 & 7,5 & - & 5,2 & 12,4 & 2,1 & - & 52,3 & 1,2 & - & 0,1 & - & 100 \\
\hline \multirow{2}{*}{$\mathrm{CN}$} & $\mathrm{f}$ & 48 & 45 & - & 59 & 78 & 33 & - & 181 & 32 & - & 12 & - & 488 \\
\hline & $\%$ & 9,8 & 9,2 & - & 12,1 & 16 & 6,7 & - & 37,1 & 6,6 & - & 2,5 & - & 100 \\
\hline
\end{tabular}

Bar graphs are used to descriptively compare the dimensions in the SBT between the countries. The percentage rates obtained from analysis of questions in Turkish and Canadian middle school mathematics textbooks according to the sub-dimensions of the cognitive processes dimension are presented in Figure 2-A. Of questions in Turkish middle school textbooks, 390 are in the "transformation" stage (72.3\%), 131 are in the "assimilation" stage (24.4\%) and 18 are in the "creation and validation" stage (3.3\%) of the cognitive processes dimension.

In Canadian middle school textbooks, 316 questions are in the "transformation" stage (64.8\%), 107 are in the "assimilation" stage $(21.9 \%)$ and 65 are in the "creation and validation" stage $(13.1 \%)$ of the cognitive processes dimension. In terms of the cognitive processes dimension, the questions in Turkish and Canadian textbooks are dominantly identified to be at the "transformation" level. Generally, while the textbooks from both countries contained similar cognitive processes dimension questions, it is noteworthy that Canadian textbooks contained more questions at the "creation and validation" level. 


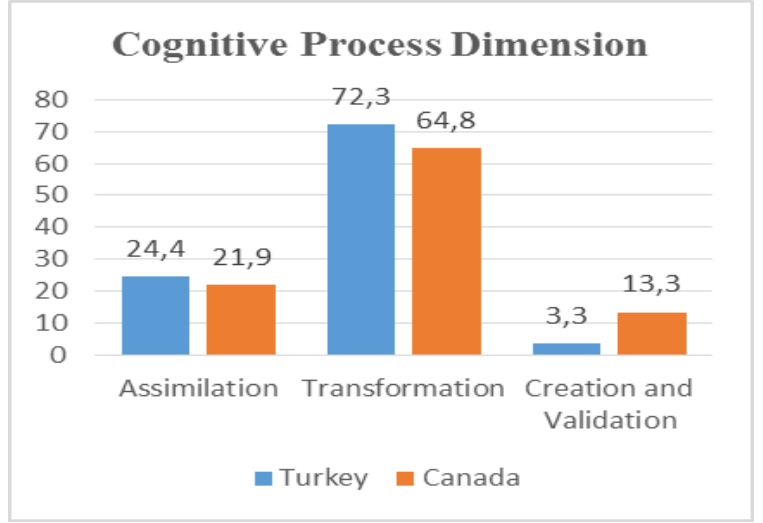

A

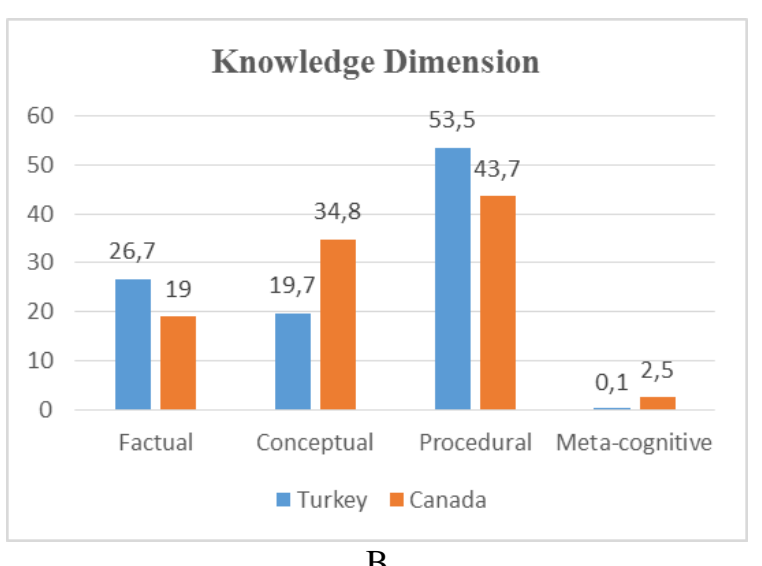

B

Figure 2. Cognitive processes dimension of questions in textbooks from Turkey and Canada (A) and distribution according to sub-levels of the knowledge dimension (B)

In Figure 2-B the questions in Turkish and Canadian middle school mathematics textbooks are analyzed according to the sub-dimensions of the knowledge dimension. Accordingly, Turkish middle school textbooks included 289 questions requiring "procedural knowledge" (53.5\%), 143 requiring "factual knowledge" (26.7\%), 106 requiring "conceptual knowledge" $(19.7 \%)$ and 1 requiring "metacognitive knowledge" (0.1\%). Canadian middle school textbooks included 213 questions requiring "procedural knowledge" (43.7\%), 170 requiring "conceptual knowledge" (34.8\%), 93 requiring "factual knowledge" $(19 \%)$ and 12 requiring "metacognitive knowledge" $(2.5 \%)$. In both countries it appears that content is dominantly at the "procedural knowledge" level for questions in middle school mathematics textbooks (Figure 2-B). Generally, while the textbooks from both countries included questions with similar knowledge dimensions, Canadian textbooks are identified to include more questions at the "metacognitive knowledge" level. Additionally, while the questions in Canadian textbooks focused on "conceptual knowledge", Turkish textbooks are identified to focus on "factual knowledge". Samples commonly encountered in both textbooks and coded as $\mathrm{C} 2$ are presented in the following examples.

From a Canadian $7^{\text {th }}$ class mathematics textbook: Find the surface area and volume of each rectangular prism. Evaluate and compare these three shapes.

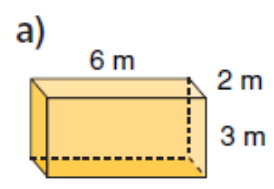

b)

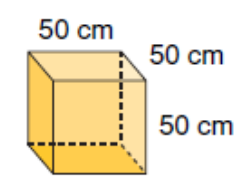

c)

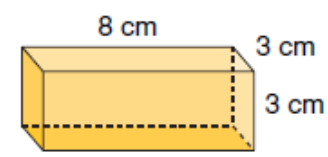

Figure 3. Sample question in a Canadian textbook from C2 level

As formula knowledge is required to calculate the area and volumes of the prisms given in this example, it is at the "procedural" level of the knowledge dimension, while as there is a transition between different shapes during the calculation process it is at the "transformation" level in terms of the cognitive processes dimension.

From a Turkish $8^{\text {th }}$ class mathematics textbook at $\mathbf{C 2}$ level: For the figures given in the following coordinate systems, draw the image of the triangle formed by offsetting to the left by 4 units along the $x$ axis and rotation clockwise around the origin by 270 degrees and draw the image of the quadrilateral formed by reflection in the $x$ axis and also clockwise rotation 90 degrees around the origin. 

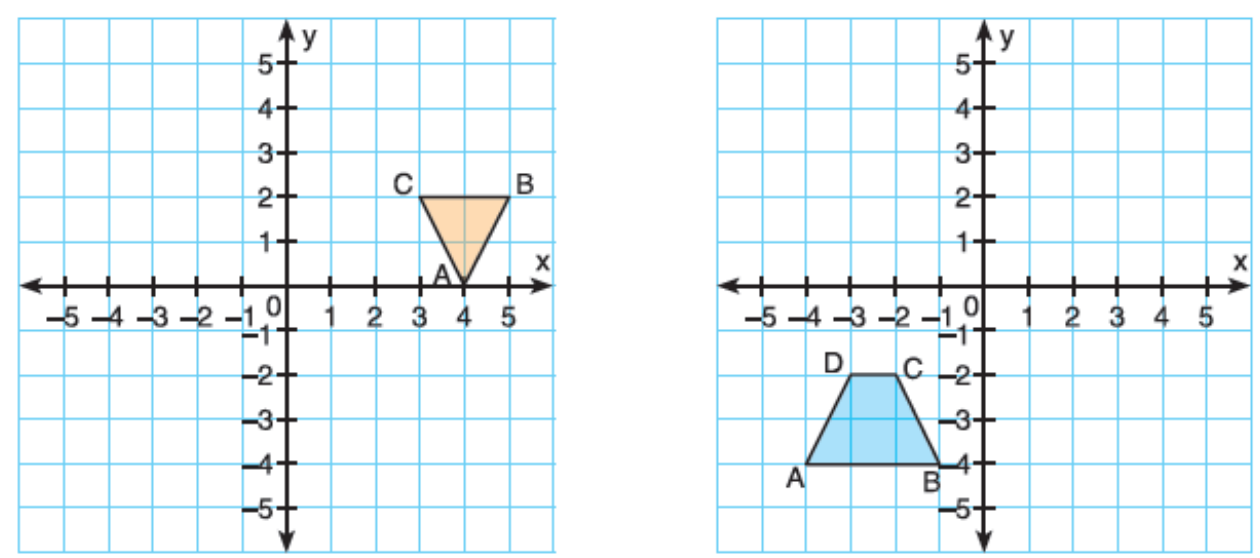

Figure 4. Sample question in a Turkish textbook from C2 level

This question is at the procedural level of the knowledge dimension and the transformation level of the cognitive processes dimension as there is a need to know the rule for offset and rotation of the shapes given and because a new geometric shape is formed in this process.

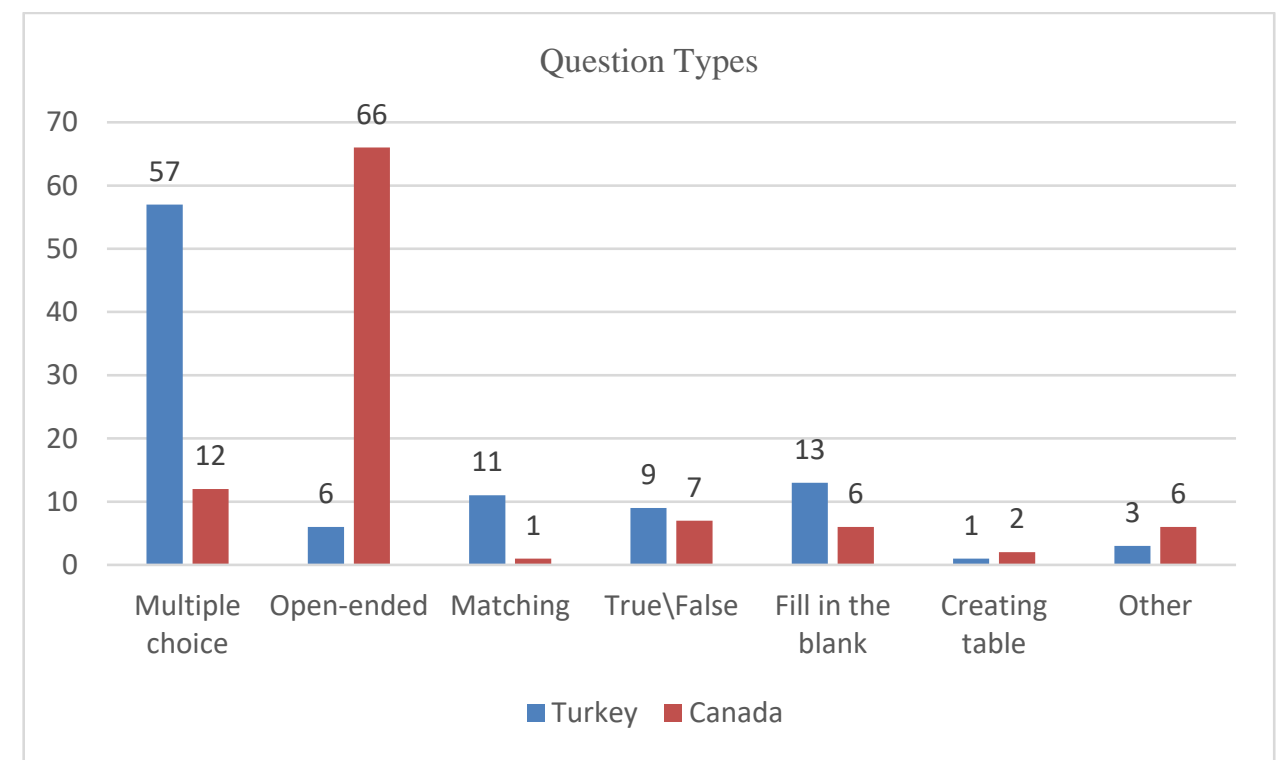

Figure 5. Distribution of question types in Turkish and Canadian textbooks

The results relating to the question types in middle school mathematics textbooks from both countries are given in Figure 4. Of the 539 mathematics questions in Turkish middle school textbooks, 311 are multiple choice (58\%), 71 are fill-in-the-blanks (13\%), 58 are matching (11\%), 47 are true/false (9\%), 31 are open-ended (6\%), 16 are other $(3 \%)$ and 5 are table fill $(1 \%)$. For Canadian middle school textbooks of 488 mathematics questions, 325 are open-ended (66\%), 57 are multiple choice (12\%), 34 are true/false (7\%), 29 are fill-in-the-blanks (6\%), 28 are other (6\%), 10 are table fill (2\%) and 5 are matching $(1 \%)$. The majority of questions in Turkish textbooks are multiple choice type questions, while the majority of questions in Canadian textbooks are determined to be open-ended. In addition, it appears that open-ended question types are not commonly found in Turkish textbooks, with more multiple choice question types used. According to these results of the study, the majority of open-ended questions in Canadian textbooks (68\%) are at the level of conceptual knowledge. Turkish textbooks commonly use fill-in-the-blanks and matching type questions and the majority of these question types are determined to be in the knowledge dimension. 


\section{DISCUSSION and CONCLUSION}

Content analysis of textbooks and comparison studies between countries actually provide hints about the educational system of a country and the instructional cycle of knowledge. The focus of the study was on cognitive level of questions in mathematics textbooks as potentially contributing to understanding the differences in the mathematical achievement of Turkish and Canadian students.

The results of this study show that in terms of the cognitive processes dimension, textbooks from Turkey and Canada most commonly include questions at the "transformation" level with fewer questions at the "creation and validation" level (see Figure 2-A). Additionally, according to the knowledge dimension, mathematics questions in textbooks from both countries are most commonly at the "procedural" level with fewer questions at the "metacognitive knowledge" level (Figure 2-B). This suggests that textbooks from both countries include questions dominated mainly by application. Similarly, when the questions in the both mathematics textbooks are compared with respect to knowledge dimension, eighth textbooks included questions that required mainly procedural knowledge. According to the cognitive process and knowledge dimensions, textbooks contain mainly average level stages which may be explained by choosing content that will communicate comprehensible messages to the majority of students in the target audience. In fact, previous researchers have shown that the teaching activities and examination questions used mainly contain content that can be understood by students at the average level (Arslan \& Özpınar, 2009; Biber \& Tuna, 2017; Güler, Özdemir \& Dikici, 2012; Köğce \& Baki, 2009; Karadeniz et al., 2015; Riazi \& Mosalanejad, 2010; Vincent \& Stacey, 2008).

For example, Biber and Tuna (2017) investigated middle school mathematics textbooks and identified that the number of questions in the upper level stages (analysis, synthesis, evaluation) are very low, and that questions generally had to be at low cognitive levels. Similarly, Delil and Tetik (2015), in a study analyzing the TIMSS-2015 cognitive areas of mathematics questions on $8^{\text {th }}$ class central examinations, determined that the large majority of $8^{\text {th }}$ class mathematics lesson questions are at application level. In fact, for students to gain higher level cognitive skills, it is necessary for the learning outcomes of the middle school mathematics program to focus on the higher level the cognitive processes dimension. However, a study by Kaplan, Baran and Hazer (2013) investigating the learning outcomes of the middle school mathematics curriculum, determined that there are fewer learning outcomes from the higher level stages, with behavior generally focused on the comprehension and application stages. On the basis of this result, it may be said that the content of textbooks is prepared to reflect the cognitive levels of learning outcomes from the current curriculum. NCTM (2000) intensely supports the skill of learner to elucidate and validate their mathematical ideas. However, the learner themselves frequently have little motivation or skill to produce high quality justifications deprived of the external aid (Ding \& Li, 2010). Students should be needed to solve a question so as to be able to validate and clarify their mathematical ideas. Likewise, for students to gain higher-level cognitive skills, there is a need for more activities and preparation of questions based on the higher-level cognitive dimensions (Zorluoğlu, Kızılaslan \& Sözbilir, 2016).

While the results of the study generally show that the textbooks from both countries contain questions with similar cognitive qualities, the basic differences between the two countries are that Canadian textbooks contain more "metacognitive knowledge" questions, while Turkish textbooks contain more "factual knowledge" questions. Some researchers have found that countries with textbook content in accordance with the international examination questions requiring metacognitive skills are more successful (Törnroos, 2005). Similarly, there are studies showing that there is a strong correlation between the mathematics achievements of students and the quality of the textbooks used (Fan, Zhu \& Miao, 2013; Kulm \& Capraro, 2008). Textbooks may be described as being a source of self-regulation for students and of guidance for teachers (Schmidt, McKnight \& Raizen, 1997; Iş1k, 2008; Thomson \& Fleming, 2004). Undoubtedly there are many factors affecting the mathematics success of countries and it is not realistic to limit the success or failure to only the quality of the textbooks. If the teacher does not teach the content, the learner do not have the opportunity to acquire it. Therefore, any lack of learning 
cannot be blamed merely on the textbook as stated by Usiskin (2013). Yet the proportion of the textbook content and how it is communicated to the students are important.

Additionally, Sevimli (2016) stated that educators even at higher level, relied on textbooks, while using different resources. As textbooks head the list of tools used in completing the internal transformation process, it may be said that the quality of the teaching materials used affect educators' behavior. Additionally, Airasian and Miranda (2002), discussing the role of measurement and evaluation in taxonomy, stated that the taxonomy's transformation to a two-dimensional structure may be beneficial in creating more open links between targets, learning processes and measurement and evaluation duties, in addition to determination of targets and more transparent planning of the learning process. The conceptual framework created with the constructivist theory led the way for student-centered applications aiming to develop higher-level thinking skills, especially. With the aim of measuring upper level thinking skills related to the creation and validation stage of the cognitive processes dimension, alternative evaluation methods such as the "degree point key" and "degree scales" for performance observation may be used.

However, the result of comparisons between the question types in textbooks determined that questions in Turkish textbooks were mainly of the multiple choice type, while open-ended type questions were more commonly used in Canadian textbooks. Students who encounter questions with content where alternative solution approaches may be used in Canadian textbooks may raise awareness about examinations like TIMSS and PISA. These international-scale examinations include constructed response questions requiring alternative solution pathways and reasoning types. A study by İncikab1 (2012) comparing the content of TIMSS and placement tests (in Turkish "Seviye Belirleme Sinavi" SBS) found no significant differences in terms of learning areas, but the SBS exam did not use openended questions as the TIMSS exam did and contained more application questions and fewer reasoning questions.

Two-dimensional taxonomy gives an opportunity to assess cognition not just in terms of knowledge but simultaneously in terms of processes (Krathwohl, 2002). This study is used two dimensional taxonomies to gather detailed information about the characteristics of textbook questions. The findings provide an opportunity for readers to think of textbooks from a broad perspective. However, three important abilities of knowing, applying, and reasoning in the cognitive learning field are more concentrated in TIMSS (ÖDSGM, 2016). Similarly, the questions in our study are classified in terms of skill levels in three cognitive areas such as 'assimilation', 'transformation' and 'creation and validation'. The classification of cognitive skills in TIMSS is equivalent to dimensions of cognitive process of SBT respectively. Two-thirds of the questions in TIMSS examinations call for the abilities of applying and reasoning. The answer of the question in the applying category concentrates on displaying conceptual understanding.

The last category involves constructed response and multi-step questions and requests learners to rationalize the solutions and employ different approaches. The results of the study suggested that the questions in Turkish and Canadian textbooks showed similar characteristics in terms of the cognitive processes and knowledge dimensions. It was found that middle school mathematics textbooks from both countries most commonly contained questions at the "transformation" stage of the cognitive processes dimension and the "procedural" level of the knowledge dimension. However, the clearest differences were that Canadian textbooks included slightly more "creation and validation" questions in terms of the cognitive processes dimension, while Turkish textbooks included more "factual" level questions in terms of the knowledge dimension. In other words, Canadian textbooks comprise more questions that require higher order thinking skill. It can be said that Canadian textbooks prioritize the improvement of higher order thinking and give learners more opportunities to explore mathematical relationships and use different approaches. Additionally, while Turkish textbooks included more multiple choice questions requiring procedural skills, Canadian textbooks more commonly used open-ended questions requiring cognitive skills. Therefore, the questions in Canadian textbooks slightly meet the cognitive domains highlighted in the TIMSS, which might be another factor that Canadian students are more successful than Turkish. 


\section{Implications}

The results of this research could help, for educators, policy makers, and teachers to consider textbooks from a different standpoint. Mathematics textbook authors should be supported to develop questions for mathematics textbooks in terms of cognitive learning. Consideration of the content of international-scale examination questions while preparing textbook content may ensure questions with higher quality are written which may then increase student awareness. When the mathematics questions in high school entrance exam of 2017-2018 in Turkey are taken into consideration, it has been seen that there is a more place given for questions types that students should read, analyze and interpret using mathematical reasoning. It is therefore recommended that the number of constructed response questions and questions requiring interpretation be increased in exercise questions in textbooks in Turkey. As this study was only completed to investigate the cognitive levels of the content of textbooks, future studies in this field should investigate different aspects of the interaction between teacher-textbook and student-textbook.

The present study has some limitations; first the examination of textbooks was limited to only mathematics questions at the end of units. Therefore, future study is needed to explore more questions in text using different taxonomy so as to gather comprehensive results regarding mathematics textbooks. Another limitation of this study was derived from the selection of four Turkish and four Canadian textbooks. Future research should examine a large number of textbooks to acquire detailed results regarding cognitive process level of mathematics questions available at textbooks utilized in different countries. Such research might contribute to clarifying the causes of the differing levels of achievement detected in past international comparative studies. Lastly, although the examination of textbooks offers evidences regarding what and how countries teach, the teaching and learning process employed in countries cannot be demonstrated in such analyses.

\section{REFERENCES}

Airasian P. W., \& Miranda, H. (2002). The role of assessment in the revised taxonomy. Theory into Practice, 41(4), 249-254.

Alajmi, A., \& Reys, R. (2007). Reasonable and reasonableness of answers: Kuwaiti middle school teachers' perspectives. Educational Studies in Mathematics, 65(1), 77-94.

Alajmi, A. H. (2012). How do elementary textbooks address fractions? A review of mathematics textbooks in the USA, Japan, and Kuwait. Educational Studies in Mathematics, 79(2), 239-261.

Anderson, L. W., \& Krathwohl, D. R. (Eds.). (2001). A taxonomy for learning, teaching, and assessing: A revision of bloom's taxonomy of educational objectives. New York: Longman.

Appel, R., Chichak, D., Jeroski, S., Morrow, P., Wortzman, R., Brown, T., Harcourt, L., Kinsman L., Nicolson, C.P. (2008). Math Makes Sense 5. Toronto, Ontorio: Pearson Education Canada.

Appel, R., D’ Amour, L., Maurer, G.S., Nicolson, P.C., Brown, T., Jeroski, S., Morrow, P., \& Sul, G. (2009). Math Makes Sense 6. Toronto, Ontorio: Pearson Education Canada.

Arslan, S., \& Özpınar, İ. (2009). Evaluation of 6th grade mathematics textbooks along with the teacher opinions. Dicle University Journal of Ziya Gökalp Faculty of Education, 12, 97-113.

Assaly, I., \& Smadi, O. (2015). Using Bloom's taxonomy to evaluate the cognitive levels of master class textbook's questions. English Language Teaching, 8(5), 100-110.

Aydın, E. (2016). Ortaokul Matematik 8. Sinıf Ders Kitabı. Milli Eğitim Bakanlı̆̆ı, Talim Terbiye Kurulu Başkanlığı. Ankara: Koza Yayın Dağıtım.

Aydın, E., \& Gündoğdu, L. (2016). Ortaokul Matematik 6. Sinıf Ders Kitabı. Milli Eğitim Bakanlığı, Talim Terbiye Kurulu Başkanlığı. Ankara: Koza Yayın Dağıtım.

Babadoğan, C., \& Olkun, S. (2006). Program development models and reform in Turkish primary school mathematics curriculum. International Journal for Mathematics Teaching and Learning. [Online]: Retrieved 10 September 2016 from http://www.cimt.plymouth.ac.uk/journal/default.htm.

Baki, A. (2008). Kuramdan uygulamaya matematik eğitimi [Mathematics education from theory to practice]. Ankara: Harf Eğitim Publishing.

Baron, L., Davis, G., Ludwig, S., Neel, K., Sidley, R., Brown, T., Jeroski, S., Milne, E., Pusic, J., \& Sufrin, D. (2008). Math Makes Sense 8. Toronto, Ontorio: Pearson Education Canada. 
Biber A. Ç., \& Tuna, A. (2017). A comparative analysis of the exercise questions in secondary school mathematics books based on learning domains and bloom's taxonomy. Ondokuz Mayıs University Journal of Faculty of Education, 36(1), 161-174.

Biggs, J. (1995). Assessing for learning: Some dimensions underlying new approaches to educational assessment. The Alberta Journal of Educational Research, 41(1), 1-17.

Bingölbali, F., Gören, A. E., \& Arslan, S. (2016). Mathematics teachers' levels of reading textbooks: an investigation within the context of the curriculum objectives. Turkish Journal of Computer and Mathematics Education, 7(2), 460-485.

Bloom, B. S. (1956). Taxonomy of educational objectives, the classification of educational goals-Handbook I: Cognitive domain. New York: McKay.

Bowen, G. A. (2009). Document analysis as a qualitative research method. Qualitative Research Journal, 9(2), 27-40.

Bulut, M. (2007). Curriculum reform in Turkey: A case of primary school mathematics curriculum. Eurasia Journal of Mathematics, Science \& Technology Education, 3(3), 203-212.

Delil, A., \& Tetik, B. Y. (2015). An analysis of Turkish eight grade high stakes mathematics examination questions based on TIMSS-2015 framework. Celal Bayar University Journal of Social Sciences, 13(4), 165-184.

Duman, T., Karakaya, N., Çakmak, M., Erayi M., \& Özkan, M. (2001). Konu alanı ders kitabı inceleme kılavuzu: Matematik 1-8 [Subject area course book review guide: Mathematics 1-8]. Nobel Publishing: Ankara.

Erbaş, A., Alacac1, C., \& Bulut, M. (2012). A comparison of mathematics textbooks from Turkey, Singapore, and the United States of America. Educational Sciences: Theory and Practice, 12(3), 2324- 2330.

Fan, L., Zhu, Y., \& Miao, Z. (2013). Textbook research in mathematics education: development status and directions. ZDM: The International Journal on Mathematics Education, 45(5), 633-646.

Garneau, M., Pusic, J., Neel, K., Jeroski, S., Ludwig, S., Sidley, R., Mason, R., \& Brown, T. (2007). Math Makes Sense 7. Toronto, Ontorio: Pearson Education Canada.

Güler, G., Özdemir, E., \& Dikici, R. (2012). A comparative analysis of elementary mathematics teachers' examination questions and SBS mathematics questions according to Bloom's Taxonomy. Erzincan University Journal of Faculty of Education, 14(1), 41-60.

Haggarty, L., \& Pepin, S. (2002). An investigation of mathematics textbooks and their use in English, French and German classrooms: who gets an opportunity to learn what? British Educational Research Journal, 28(4), 567-590.

Hirsch, C., Lappan, G., Reys, B., \& Reys, R. (2005). Curriculum as a focus for improving school mathematics. Mathematicians and Education Reform Forum Newsletter, 18(1), 12-14.

Işık, C. (2008). The factors affecting the use of mathematics textbook of mathematics teachers at primary education (Grades 6-8) and their expectations. Kastamonu Journal of Faculty of Education, 16(1), 163-176.

İncikabi, L. (2012). After the reform in Turkey: A content analysis of SBS and TIMSS assessment in terms of mathematics content, cognitive domains, and item types. Education as Change, 16(2), 301-312.

Kaplan, Z., Baran, T., \& Hazer, Ö. (2013). A study of the target behaviors in the math curriculum for sixth to eighth grades in reference to cognitive processes. Ahi Evran University Kırşehir Journal of Faculty of Education (KEFAD), 14(1), 347-366.

Kar, T., Güler, G., Şen, C., \& Özdemir, E. (Accepted, 2017). Comparing the development of the multiplication of fractions in Turkish and American textbooks. International Journal of Mathematical Education in Science and Technology, http://dx.doi.org/10.1080/0020739X.2017.1355993.

Karadeniz, M., Baran, T., Gökçek, T., \& Güç, F. (2015). Contextual examination of the Turkish middle school mathematics teachers' exam questions. In Adams. G. (Ed.), Proceeding of the British Society for Research into Learning Mathematics, Vol. 35(2) (pp. 90-95). London, UK: BSRLM.

Karakaya, S. (2004). A comparative study: English and Turkish teachers' conceptions of their professional responsibility. Educational Studies, 30(3), 195-216.

Keskin, C. (2016). Ortaokul Matematik 7. Sinıf Ders Kitabı. Milli Eğitim Bakanlı̆̆ı, Talim Terbiye Kurulu Başkanlığı. Ankara: Koza Yayın Dağıtım.

Köğce, D. \& Baki, A. (2009). Comparing mathematics questions' levels in different type of high schools according to Bloom Taxonomy. Kastamonu Journal of Faculty of Education, 17(2), 557-574.

Krathwohl, D. R. (2002). A revision of Bloom's taxonomy: An overview. Theory into Practice, 41(4), 212-218.

Kulm G., \& Capraro R. M. (2008). Textbook use and student learning of number and algebra ideas in middle grades. In Kulm G. (Ed.), Teacher knowledge and practice in middle grades mathematics (pp. 255272). Rotterdam, The Netherlands: Sense.

Kurtulmuş, Y. (2010). Teachers' opinions about 8th grade primary school mathematics textbooks. (Unpublished Master Thesis). Mustafa Kemal University, Hatay.

Li, Y., Chen, X., \& An, S. (2009). Conceptualizing and organizing content for teaching and learning in selected Chinese, Japanese and US mathematics textbooks: The case of fraction division. ZDM: The International Journal on Mathematics Education, 41(6), 809-826. 
Miles, B., M., \& Huberman, A., M. (1994). Qualitative data analysis (21 Ed.). London: Sage Publication.

Ministry of National Education [MEB]. (2017). 1-8th grade mathematics education curriculum. Ankara: Board of Education Publications.

Mullis, I.V.S., Martin, M.O., Foy, P., \& Arora, A. (2012). TIMSS 2011 International Results in Mathematics. Chestnut Hill, MA: TIMSS \& PIRLS International Study Center, Boston College.

NCTM. (2000). Principles and standards for school mathematics. Reston, VA

Olkun, S. (2006). Yeni ögretim programlarını inceleme ve değerlendirme raporu: Matematik ögretim programı inceleme raporu [New curriculum review and evaluation report: Mathematics curriculum review report]. $\begin{array}{lllll}\text { Retrieved } & 11 & \text { September } & 2017 & \text { from }\end{array}$ online.org.tr/vol5say1/yenimufredat_raporu\%5B1\%5D.pdf.

ÖDSGM. (2016). TIMSS 2015 Ulusal Matematik ve Fen Bilimleri ön raporu 4. ve 8. sinıflar. Ankara.

Özer, E., \& Sezer, R. (2014). A comparative analysis of questions in American, Singaporean, and Turkish mathematics textbooks based on the topics covered in 8th grade in Turkey. Educational Sciences: Theory \& Practice, 14(1), 411-421.

Pepin, B., \& Haggarty, L. (2001). Mathematics textbooks and their use in English, French and German classrooms: a way to understand teaching and learning cultures. ZDM: The International Journal on Mathematics Education, 33(5), 158-175.

Porter, A. C. (2002). Measuring the content of instruction: Uses in research and practice. Educational Researcher, 31(7), 3-14.

Reys, B. J., Reys, R. E., \& Chavez. O. (2004). Why mathematics textbooks matter. Educational Leadership, 61(5), 61-66.

Rezat, S. (2009). The utilization of mathematics textbooks as instruments of learning. In Durand- Guerrier V, Soury-Lavergne S, Arzarello F. Proceedings of Congress of European Research in Mathematics Education 6; Lyon, p. 1260-1269.

Riazi, A., \& Mosalanejad, N. (2010). Evaluation of learning objectives in Iranian high-school and pre-university English textbooks using Bloom's Taxonomy. The Electronic Journal for English as a Second Language, $13(4), 1-16$

Rizvi, N. S. (2007). A synthesis of taxonomies/frameworks used to analyse mathematics curricula in Pakistan. In D. Kuchemann (Ed.), Proceeding of the British Society for Research into Learning Mathematics Vol. 27(3) (pp. 90-95). Contributions of the day conference, Northampton, UK, 17 November 2007. London, UK: BSRLM.

Schmidt, W., McKnight, C. \& Raizen, S. (1997). A splintered vision: An investigation of U.S. science and mathematics education. Boston: Kluwer.

Sevimli, E., \& Kul, Ü. (2015). Evaluation of the contents of mathematics textbooks in terms of compliance to technology: case of secondary school. Necatibey Faculty of Education Electronic Journal of Science and Mathematics Education, 9(1), 308-331.

Sevimli, E. (2016). Investigation of structural features of examples which textbook located and lecturers' preferred in calculus. Education and Science, 41(183), 319-338.

Smith, G., Wood, L., Coupland, M., \& Stephen, B. (1996). Constructing mathematical examination to assess a range of knowledge and skills. International Journal of Mathematical Education in Science and Technology, 21(1), 65-77.

Son J.W. (2012). A cross-national comparison of reform curricula in Korea and the US in terms of cognitive complexity: The case of fraction addition and subtraction. ZDM: The International Journal on Mathematics Education, 44(2), 161-174.

Sriraman, B. (2010). Mathematics education in Turkey: At the crossroads of cultural, political, and economic currents. ZDM: The International Journal on Mathematics Education, 42, 421-427.

Stein, M., Remillard, J., \& Smith, M. (2007). How curriculum influences students' learning. In F. Lester (Ed.), Second handbook of research on mathematics teaching and learning (pp. 557-628). Charlotte: Information Age.

Taşdemir, C. (2011). Evaluating of mathematic lesson books taught in first grade of elementary school according to the views of teachers. Dicle University Ziya Gökalp Journal of Faculty of Education, 16, 16-27.

Thomson, S., \& Fleming, N. (2004). Summing it up: Mathematics achievement in Australian schools in TIMSS 2002. Melbourne: ACER.

Törnroos, J. (2005). Mathematics textbooks, opportunity to learn and student achievement. Studies in Educational Evaluation, 31(4), 315-327.

Türkyılmaz, M. (2008). The opinions of teachers about the usage of essay examinations as a measurement tool in language and expression course. Ahi Evran University Kırşehir Journal of Faculty of Education (KEFAD), 9(3), 1-14.

Ubuz, B., \& Sarpkaya, G. (2014). The investigation of algebraic tasks in sixth grades in terms of cognitive demands: mathematics textbook and classroom implementations. Elementary Education, 13(2), 594-606. 
Usiskin, Z. (2013). Studying textbooks in an information age-a United States perspective. ZDM: The International Journal on Mathematics Education, 45(5), 713-723.

Vincent, J., \& Stacey, K. (2008). Do mathematics textbooks cultivate shallow teaching? Applying the TIMSS Video Study Criteria to Australian eighth-grade mathematics textbooks. Mathematics Education Research Journal, 20(1), 82-107.

Yaman, H., Akkaya, R., \& Yeşilyurt, Ü. (2016). Ortaokul Matematik 5 Sinıf Ders Kitabı. Milli Eğitim Bakanlığı, Talim Terbiye Kurulu Başkanlığı. Ankara: Koza Yayın Dağıtım.

Yıldırım, A. \& Şimşek, H. (2008). Sosyal Bilimlerde Nitel Araştırma Yöntemleri (6 ${ }^{\text {th }}$ Ed.). [Qualitative Research Methods in the Social Sciences (6. Edition)]. Ankara: Seçkin Yayıncılık.

Zorluoğlu, S. L., Kızılaslan, A. \& Sözbilir, M. (2016). School chemistry curriculum according to revised bloom taxonomy. Necatibey Faculty of Education Electronic Journal of Science and Mathematics Education, 10 (1), 260-279. 


\section{TÜRKÇE GENIŞLETILMIŞ ÖZET}

Bu çalışmanın amacı, Türkiye ve Kanada'da kullanımda olan ortaokul matematik ders kitaplarındaki soruları bilişsel öğrenme düzeylerine ve soru türlerine göre inceleyip karşılaştırmaktır. Milli Eğitim Bakanlığg Talim Terbiye Kurulunca onaylanan ders kitapları, öğrenciler için öz düzenleme, öğretmenler için ise bir rehber kaynak olarak tasvir edilebilir (Schmidt, McKnight \& Raizen, 1997; Işık, 2008; Thomson \& Fleming, 2004). Ders kitapları, Uluslararası Matematik ve Fen Eğilimleri Araştırması ve Uluslararası Öğrenci Başarılarını Değerlendirme Programı gibi geniş ölçekli değerlendirme sınavlarında, öğrencilerin başarılarındaki farklılıkları tespit etmek amacıyla kullanılmaktadır (Alajmi, 2012). TIMSS (Trends in International Mathematics and Science Study) 2015 değerlendirme raporuna göre 8. sınıf düzeyi matematik başarısı anlamında 527 puanla 8. olan Kanada, İngilizce konuşan ülkeler arasında da en yüksek matematik başarısına sahip ülkedir. Aynı sınavda Türkiye, 458 puan ile 39 katılımcı ülkelenin ortalama başarı puanı olan 500 puanın altında kalarak 24. sırada yer almaktadır (ÖDSGM, 2016). Öğretme-öğrenme sürecinin etkililiğine katk1 sağlayan bileşenlerden biri ders kitapları olup, uluslararası düzeydeki merkezi değerlendirme sınavlarına göre ülkelerin matematik başarıları ve ders kitabı kalitesi arasındaki ilişkileri sorgulayan çeşitli araştırmalar mevcuttur (Delil \& Tetik, 2015; Erbaş, Alacac1 \& Bulut, 2012; Fan, Zhu \& Miao, 2013). Bu çalışmada Türkiye ve Kanada'da kullanılmakta olan ortaokul matematik ders kitaplarında yer alan ünite sonu değerlendirme soruları 'bilişsel süreç' ve 'bilgi boyutu' bağlamında değerlendirilmiştir. Bu amaç doğrultusunda aşağıdaki iki soruya cevap aranmıştır: (1) Türkiye ve Kanada ortaokul matematik ders kitabında yer alan matematik sorularının Sentezlenmiş Bloom Taksonomisi (SBT)'ne göre düzeyi nedir? (2) Türkiye ve Kanada ortaokul matematik ders kitabında yer alan matematik soruların türleri arasında bir farklılık var mıdır?

Bilimsel bilgilerden hangilerinin öğretilecek bilgiler olduğunu belirten kaynaklardan biri ders kitapları olup (Chevalard, 1991), ders kitaplarındaki içeriklerin bilişsel alan taksonomisindeki yeterlikler bağlamında değerlendirildiği bu araştırmada (Rizvi, 2007) ulusal içerikler uluslararası bir perspektiften karşılaştırıldığından çalışma üzerinden elde edilecek sonuçların önemli olduğu düşünülmektedir (Haggarty \& Pepin, 2002; Törnroos, 2005). Bu doğrultuda, Türkiye'de kullanılan 5, 6, 7 ve 8. sınıf matematik ders kitapları ile Kanada'da kullanılmakta olan "Math Makes Sense" adlı ders kitapları seti içerik analizine tabi tutularak karşıllaştııılmıştır. Araştırmanın amacına uygun olarak veriler toplanıp doküman analizi yapılmıştır. Her iki ülke ders kitaplarında yer alan matematik soruları, Rizvi (2007) tarafından geliştirilen SBT değerlendirme çerçevesine göre bilişsel süreç ve bilgi boyutlarına bağlamında kodlanmış, soruların benzerlik ve farklılıkları karşılaştırmalı olarak incelenmiştir. $\mathrm{Bu}$ çalışmada iki ülkeye ait matematik ders kitaplarının SBT açısından değerlendirilebilmesi için ünite sonunda yer alan alıştırma ve değerlendirme soruları kullanılmıştır. Verilerin analizinde betimsel istatistik (yüzde/frekans) yöntemlerinden yararlanılmıştır. Ortaokul matematik ders kitaplarındaki soruların incelenmesi 3 aşamada gerçekleşmiştir. Birinci aşamada, her iki ülke ders kitabından rastgele bir üniteye ait değerlendirme soruları seçilmiştir. Konuyla ilgili sorular, üç araştırmacı tarafindan taksonomi tablosuna göre yerleştirilmiştir. Bunun için öncelikle iki ülkenin matematik ders kitapları yüzeysel olarak incelenmiştir. Daha sonra ders kitabındaki soruların taksonomi tablosuna yerleştirilmesinde kullanılacak temel prensipler araştırmacılar tarafından belirlenmiştir. Buna göre, matematik sorularındaki ifadelerin bilişsel süreç boyutunu yansıtan fiilleri ile bilgi boyutunu yansıtan ad bölümleri detaylı bir şekilde konuşulmuş, ortak fiiller ve adlar (anahtar kelimeler) belirlenmiştir. $\mathrm{Bu}$ süreçte elde edilen anahtar ifadelerin (gösterme, anlama, tahmin etme ve karşılaştırma vb.) ardından, Türkiye ve Kanada ders kitaplarında yer alan ünite sonu değerlendirme sorularının her birinin bilgi boyutunun bulunduğu satır ile bilişsel süreç boyutunun bulunduğu sütunun kesişimi olan hücre tespit edilerek matematik sorularının SBT'deki yeri belirlenmiştir (Krathwohl, 2002). Örneğin, 6. sınıf ders kitabında "Aşağıdaki şekillerden hangisinde bir çemberin yarıçapı gösterilmiştir?" sorusunda "göstermek" fiil ifadesi özümseme basamağında, "şekillerden hangisinde bir çemberin yarıçapı" ad ifadesi temel kavram içerdiğinden olgusal basamakta (A1) yer almaktadır. İkinci aşamada matematik soruları araştırmacıların her biri tarafından bağımsız olarak kodlanmıştır. Üçüncü aşamada ise kodlayıcılar arası güvenirlik belirlenmiştir. Bu aşamada araştırmacılar tekrar bir araya gelerek 
taksonomi tablosunda uyuşmayan yerleri tespit etmiştir. Daha sonra araştırmacılar tarafından kodlamada uyuşmayan sorular tartışılarak ortak bir görüşe varılmıştır. Bu süreçte gerekli görülen yerlerde yine ölçme ve değerlendirme ana bilim dalındaki öğretim üyelerinden uzman görüşü alınmıştır.

Türkiye ve Kanada ders kitaplarında yer alan soruların bilişsel süreç ve bilgi boyutu açısından benzer özellikler gösterdiği tespit edilmiştir. Ancak Kanada ders kitabında bilişsel beceri gerektiren açık uçlu soru türlerine yüzde 60 daha fazla yer verildiği belirlenmiştir. Bu çalışmadaki bulgular, bilişsel süreç boyutu bağlamında Türkiye ve Kanada ders kitaplarında "dönüştürme" düzeyindeki soruların daha sık, "özümseme" düzeyindeki soruların ise daha az yer aldığını göstermiştir (Şekil 2-A). Ayrıca, bilgi boyutuna göre her iki ülke ders kitabındaki matematik sorularında, en çok "işlemler" düzeyinde, en az ise "üstbilişsel bilgi" düzeyinde sorulara yer verildiği belirlenmiştir (Şekil 2-B). Şekillerden de anlaşılacağı üzere her iki ülke ders kitaplarında daha çok uygulama ağırlıklı sorular yer almaktadır. Ders kitaplarında bilişsel süreç ve bilgi boyutlarının orta düzeydeki basamaklarına daha sık yer verilmesi daha geniş bir öğrenci kitlesi tarafından anlaşılabilecek içeriklerin tercih edilmesi ile açıklanabilir. Nitekim önceki araştırmalarda kullanılan öğretim etkinliklerinde ve sınav sorularında ortalama düzeydeki öğrencilerin anlamlandırabileceği türdeki içeriklere daha fazla yer verildiğini göstermektedir (Arslan \& Özpınar, 2009; Biber \& Tuna, 2017; Güler, Özdemir \& Dikici, 2012; Köğce \& Baki, 2009; Karadeniz, Baran, Gökçek \& Güç, 2015; Riazi \& Mosalanejad, 2010; Vincent \& Stacey, 2008). Ders kitabı içeriği hazırlanırken uluslararası ölçekli sınav sorularının içeriklerinin de göz önünde bulundurulması, söz konusu sınavlarla daha uyumlu soruların yazılmasını sağlayabilir ve bu durum, öğrencilerin başarısını arttırabilir. Ülkemizde bu yıl gerçekleştirilen liselere giriş sınavındaki matematik soruları göz önüne alındığında, öğrencilerden okuduğunu anlamasını, analiz etmesini ve yaptığı çıkarımlarla çözüme ulaşmasını sağlayan soru türlerine daha çok yer verildiği görülmüş̧tür. Bundan dolayı birincil kaynak olarak kullanılan ders kitaplarında öğrencilerin üst düzey düşünmelerini sağlayan açık uçlu ve yorum gerektiren soru türlerinin sayısı arttırılabilir. Bu araştırma sadece ders kitabındaki içeriklerin bilişsel düzeylerini incelemek üzere yapılmış olduğundan, ilgili alanda yapılacak gelecek çalışmalar için öğretmen-ders kitabı ve öğrenci-ders kitabı arasındaki etkileşimi farklı yönlerden inceleyen çalışmalara yer verilebilir. 